Mavi Atlas, 9(2)2021: 191-201

Makale Geliș | Received: 08.10.2021

Makale Kabul | Accepted: 17.10.2021

DOI: 10.18795 /gumusmaviatlas.1006438

Araştırma Makalesi | Research Article

\author{
Erkan DİKİĊ் \\ Dr. Öğr. Üyesi | Asst. Prof. \\ Gümüşhane Üniversitesi, Edebiyat Fakültesi, Sosyoloji Bölümü, Gümüşhane-TÜRKIYYE \\ Gümüşhane University, Faculty of Literature, Departmant of Sociology, Gümüşhane-TURKEY \\ ORCID: 0000-0001-8319-0345 \\ dikicierkan@gmail.com
}

\title{
Sosyolojinin Ne’liği ve Kim'liği Üzerine Bir Değerlendirme
}

\section{Öz}

Sosyolojinin bilim dalı olarak 19. yüzyılda Avrupa'da ortaya çıkışı, günümüzde kabul edilen bir gerçekliktir. Özellikle Sanayi Devrimi ve Fransız İhtilali ile özdeşleştirdiğimiz sosyolojinin bilim olma serüveni, temelinde Batı merkezli bir anlayış çerçevesinde şekillenmiştir. Bir kriz bilimi olarak da ifade edilen ve Batı toplumunun sorunlarına çözüm aramak gayesinde olan Batı sosyolojisinin zamanla tüm dünya toplumları hakkında söz söyleme hakkını kendisinde gördüğü bir tarihsel süreç yaşanmıştır. Nitekim bu süreç, Osmanlı Devleti/Türkiye gibi, Bat1-dışı toplumlar tarafindan olduğu gibi kabul edilmek durumunda kalmış ve bu toplumlar tarafindan Batı'da ortaya çıkan sosyoloji anlayışı genellikle aktarmacı bir zihniyetle takip edilmiştir. Zamanla sosyolojinin Batı-dışı toplumlar tarafindan bir bilim olarak icra edilmesi, Batı merkezli sosyoloji anlayışının yeterli bulunmamasına, eleştirilmesine neden olmuştur. Özellikle Türkiye gibi Fransa'dan sonra sosyolojinin akademik ve bilimsel açıdan gelişim gösterdiği ülkelerde, Batı sosyoloji anlayışının ve terminolojisinin Batı-dışı toplumları açıklamakta yetersiz kalacağı ve yerli anlayışların geliştirilebileceği düşüncesi ön plana çıkmıştır. Bu durumun gelişim göstermesinde Batı merkezli sosyoloji anlayışının kapitalist sistemi meşru hâle getiren bir tarafı olmasına yönelik düşüncelerin de var olması etkili olmuştur. Bu açıdan bakıldığında makalenin konusunu Türkiye'de yaklaşık yüz yıllık bir tarihi olan sosyolojinin yerli bir anlayışla Batı sosyolojisine olan eleştirel bakış açısı oluşturmaktadır. Makalede Batı sosyoloji anlayışının Batı-dışı toplumlar tarafindan olduğu gibi kabul edilmemesi neticesinde günümüz Türk sosyologlarının Batı merkezli sosyoloji anlayışının ne’liği ve kim'liğine yönelik görüş ve eleştirilerin ortaya konması amaçlanmıştır. Makalede öncelikle Batı'da sosyolojinin gelişim serüveni ele alınacak, Batı merkezli sosyoloji anlayışının kapitalist sistemi meşrulaştırma konusundaki durumuna yer verilecek ve son olarak günümüz Türk sosyologlarından hareketle Batı sosyolojisinin ne'liği ve kim'liği üzerine bir değerlendirme yapılacaktır. Bu bağlamdan hareketle bir derleme türü olan makalede, doküman incelemesi yöntemi kullanılarak literatür taraması sonucu ulaşılan kaynaklardan konunun analizi yapılmıştır.

Anahtar Kelimeler: Sosyoloji, Türk Sosyolojisi, Yerli Sosyoloji, Batı Sosyolojisi, Kapitalizm.

\section{An Evaluation Upon the Nature and Identity of Sociology}

\begin{abstract}
Today, it is an accepted reality that the emergence of sociology as a branch of science occurred in Europe in the nineteenth century. The adventure of sociology so as to be a science, which we associate especially with the Industrial Revolution and the French Revolution, has been shaped in the framework of a Western-centered understanding. Eventually, a historical process has been experienced through which Western sociology, which is also depicted as a science of crisis and strives to find solutions corresponding to the problems of Western society, is eligible to have a say about all world societies over time. Thus, this process had to be accepted as it was by nonWestern societies such as the Ottoman Empire/Turkey, and the understanding of sociology that emerged in the West was usually followed with a transferrist mentality. In time, the practice of sociology as a science by non-Western societies caused the Western-centered understanding of sociology to be insufficient and to be critiqued. Especially in countries like Turkey, where sociology has developed academically and scientifically after France, the conception that Western sociological understanding and terminology will be inadequate to explain non-Western societies and that native conceptions might be developed has come to the forefront. The development of this situation was influenced by the fact that there were thoughts suggesting that the Western-centered understanding of sociology legitimizes the capitalist system. Considering this point of view, the subject of the article is the critical perception of sociology, which has a history of nearly a century in Turkey, to Western sociology with a native understanding. In the article, it is aimed at revealing the views and criticisms of today's Turkish sociologists concerning the nature and identity of
\end{abstract}


the Western-centered sociological understanding in accordance with the fact that the Western understanding of sociology is not accepted as it is by non-Western societies. In the article, first of all, the development adventure of sociology in the West will be discussed, and then the situation of the Western-centered understanding of sociology in legitimizing the capitalist system will be included, and finally, an evaluation will be made on the nature and identity of Western sociology, based on contemporary Turkish sociologists. Within this context, in the article, which is a compilation type, the analysis of the subject was fulfilled from the sources reached as a consequence of the literature review by using the document review method.

Keywords: Sociology, Turkish Sociology, Native Sociology, Western Sociology, Capitalism.

\section{Giriş}

18. yüzyılın sonları ve 19. yüzyılın başları dünya tarihi açısından önemli bir zaman dilimi olarak görülmektedir. Bu zaman diliminin önemi, Batı merkezli bir anlayışın inşası olarak karşımıza çıkmaktadır. Batı'da yaşanan bir takım siyasi, ekonomik ve toplumsal gelişmeler, bu durumun hazırlayıcısı durumundadır. Sosyal hayatın bütünüyle etkilenmesi ve değişimin yaşanması bakımından 19. yüzyıl, kurmuş olduğu Batı merkezli anlayış çerçevesinde toplumsal yapının değişimine de sebep olmuştur. Yeni bir toplum anlayışı karşısında Batı, düzen(sizlik) sorunu ile karşı karşıya kalmıştır.

19. yüzyılda Batı'da baş gösteren düzen(sizlik) sorunu, toplumsal yapı üzerinde bir ihtiyacı hissettirmiştir. Bu ihtiyaç, her ne kadar Batı merkezli bir anlayışın ürünü olsa da ihtiyacı karşılama noktasında kendi dışında çözümler arayan bir Batı'dan bahsetmiş olmaktayız. Sezgin Kızılçelik'in (2015a, s. 47) belirttiği gibi "akıl ve akılcılaştırma üzerine inşa edilmiş" bir Batı uygarlığından söz edilmektedir. Uygarlığının inşasında aklı ön plana çıkartan Batı, bir taraftan dünya egemenliğini ele geçirirken, diğer taraftan bir takım sorunlarla yüzleşmek zorunda kalmıstır. Batı'da 19. yüzyılda ortaya çıkan sorunlu durumlara ve değişmelere kaynaklık eden faktörlerin başında devrimler gelmiştir. Devrimler, dünya tarihini biçimlendiren, toplumları dönüştüren/değişsiren ve insanlığ1 yönlendiren olaylar olarak kabul edilmiştir (Kızılçelik, 2005, s. 14). "Batı, bu yüzyılda dünya egemenliğini ele geçirmiş ve özellikle Batı-dışı mazlum toplumları hegemonyası altına almaya başlamışır. Batı'nın dünya üzerinde hükümranlık kurmasına ve çeşitli sorunlarla yüz yüze gelmesine kaynaklık eden oluşumların başında Endüstri Devrimi ile Fransız Devrimi gelmektedir" (Kızılçelik, 2005, s. 130). Sanayi Devrimi ve Fransız İhtilali ile Batı'da gerçekleşen dönüşüm sonrası önemli bazı sonuçlar elde edilmiştir. Toplum sorunlarına çok yönlü ve boyutlu çözümler arandığı bir sırada, bilimsel ele alışların Batı'da yeni bir bilimin, sosyolojinin doğuşuna yol açmıstır (Tuna, 1991, s. 29).

19. yüzyılda Bat1, Doğu karşısında elde etmiş olduğu üstünlüğünü ya da dünya egemenliğini sürdürebilme noktasında sosyal olay, konu ve sorunlar üzerinde daha doğru bilgilere gereksinim duymuştur. Böylesi bir gereksinimin/anlayışın ürünü olarak Batı'da sosyoloji adlı yeni bir sosyal bilim disiplini üretilmiştir (Kızılçelik, 2004a, s. 73). Baykan Sezer'e (2011, s. 32) göre, sosyolojinin tüm çabası toplum olaylarının anlaşılması ve bilinmesine yöneliktir. Bu çabanın sosyoloji ile başlamadığını, insanlık tarihi kadar eski olduğunu öne sürmektedir. Çünkü 19. yüzyılda Batı, bazı bilgiler aracıllğıyla toplum olayları üzerinde etkili olabileceği ve bu olaylara yön verebileceği inancına kavuşmuştur. Batı'da toplumsal sorunlar üzerine yaşanan gelişmeler, yeni bir bilim olarak sosyolojinin varlığının bir ispatı gibi düşünülebilir. Koyuncu ve Bozkurt'a (2019, s. 93) göre 19. yüzyılda Batı'da yaşanan sorunlara çözüm getirme çabalarılyla sosyoloji bilimi ortaya çıkmıștır. Batı'da ortaya çıkan yeni toplumsal sorunlar ve bu sorunlara karșı düzen arayıșı ve dünya egemenliğinin meşruluğu problemlerinin çözümü için sosyoloji araçsal bir şekilde kullanılmıştır. Ülkemizde Batı’nın sorunlarına karşı geliştirilen çözüm reçeteleri alınıp Türk toplumunun sorunlarına hazır reçete olarak sunulmuştur. Ancak Türk sosyolojisi bütünüyle bu taklitçi ve nakilci yaklaşımdan ibaret olmamıştır.

İnsanı ve toplumu ilgilendiren sorunların düşünürler/bilim adamları tarafindan ele alınmasının, 19. yüzyıl ya da insanlık tarihi içerisinde herhangi bir zaman dilimi ile ilişkilendirilmesi 
kabul edilemez. Mehmet Zencirkıran'ın (2015, s. 23) belirttiği üzere insanlık tarihi boyunca düşünürler, insan ve toplum hayat1 ile ilgili birçok sorun ortaya koymuş ve bu sorunlara çözüm önerileri getirmeye çalışmıslardır. Ona göre insan ve topluma dair yapılan sorgulamalar, tarihin oldukça eski zamanlarına kadar götürülebilir. Fakat sosyolojinin sistematik bir bilim dalı hâline gelmesinde sanayi devrimine büyük önem atfetmektedir. $O$, sosyolojiyi endüstri devrimi ile beraber sosyal yaşamda devrim niteliğinde gerçekleşen dönüşüm, kaos ya da altüst oluşlara, o dönemde beliren sorunlara çözüm getirme çabası içerisinde olan bir bilim dalı olarak kabul etmektedir.

Sosyolojinin yeni bir bilim dalı olarak ortaya çıkışı noktasında zaman dilimi bakımından 19. yüzyllı işaret etsek de sosyolojinin ortaya çıkışı birden bire gerçekleşen bir durum değildir. H. Bayram Kaçmazoğlu (2001, s. 10-11), sosyolojinin bir bilim hâline gelişinin arka planını Ortaçă̆ sonlarına kadar götürmektedir. Ona göre Ortaçağın sonlarına doğru Batı'da ortaya çıkan bir takım değişimler, keşifler, Doğu-Batı ilişkileri ve bu ilişkiler sonucunda görülen sınıfsal dönüşümler, bilimsel gelişmelerin teknik buluşlara ivme kazandırması, 18. yüzyılın ortalarından itibaren ticaret burjuvazisinin ve ardından sanayi burjuvazisinin doğmasına yol açmıştır. Bu değişim ve dönüşümlerin burjuvazi sınıfı adına en belirgin kazanımının, Fransız Devrimi olduğuna işaret etmiştir. Kaçmazoğlu, sosyolojinin bilim hâline gelişinde yalnızca Fransız Devrimi'ni örnek göstermemiştir. Bu dönemin bir devamı olarak 19. yüzyılda işçi sınıfının ve çoğunluğunu işçi sınıfinın oluşturduğu siyasal hareketlerin ortaya çıkışına temas etmiştir. Ona göre bu dönemde somut hâle gelen Batılı toplumların genel özellikleri ve yeni ortaya çıkmaya başlayan toplumsal sorunlar, geleneksel/feodal olma özelliğine sahip Batı'dan nakledilen bilimlerle çözülemediğinden dolayı yeni bir bilime ihtiyaç hissedilmiştir. Batı toplumunun sahip olduğu gerçekleri ve yaşanan dönüşümü izah edebilecek özelliğe sahip olan bilime duyulan ihtiyaç sosyoloji aracillğı ile giderilmek istenmiştir.

Batı'da sosyolojinin yeni bir bilim olarak toplumsal gerçeklikleri ve yaşanan dönüşümü açıklama arzusu/beklentisi, aslında Batı'daki toplumsal yapıda yaşanan düzen(sizlik) ile alakalıdır. Baykan Sezer (1993, s. 13), 19. yüzyılda Avrupa'nın batısındaki ülkeleri belirleyen ve sosyolojinin başlıca yönelimlerini kavrayabilmemize izin veren birtakım özellikler olduğunu belirtmektedir. Ona göre bir taraftan Batı'nın dünya genelinde ve doğa üzerinde kazandığı egemenlik/üstünlük, diğer taraftan ise aynı ülkelerin kendi toplumları içinde tarihlerinde tanık olmadıkları sorunlarla karşılaşmaları şeklinde bir gerçeklik söz konusudur. Batı'nın dünya genelinde ve doğa üzerinde kazandığ1 bu etkinliğini, kendi toplumunda yaşanan iç sorunları çözüme kavuşturmak adına kullanmak isteyecektir. Batı'nın elde ettiği etkinliği bilinçli bir şekilde kullanması, sorunlarının üstesinden gelebileceği anlamına gelmektedir. Baykan Sezer'e göre Batı, dünyaya egemen olma ve dünyaya istediği yönü verebilme gücüne sahip olduğunu düşündüğü için Batı'da var olan toplumsal sorunların da kolay bir şekilde üstesinden geleceğine inanmaktadır. Fakat çalışmanın konusu itibariyle bakıldığında Batı'da ortaya çıkan, gelişen ve bilim kimliği kazanan sosyolojinin yalnızca sorunların çözümünde değil, aynı zamanda yeni sorunların da ortaya çıkmasına neden olduğu varsayılmaktadır. Çünkü Batı merkezli bir anlayışa sahip olan bir bilim olarak sosyoloji, aynı zamanda kapitalist sistemi meşrulaştıran bir özelliğe de sahip olmuştur. Bu bağlamdan hareketle, Şan ve Şenkaloğlu'nun (2019, s. 38) da ifade ettiği şekilde Batı sosyolojisinin sadece Batı toplumlarının özellikleri ve sorunları ile sinırlandırılması ona ne bilim hüviyeti kazandırır ne de diğer toplumların sorunlarını çözebilen bir disiplin olma imkânı verir. Kısacası Batı sosyolojisi, 19. yüzyılda ortaya çıktı̆̆ı dönemde doğasına egemen olan Avrupa merkezci bakış açısı ile sorunlar karşısında yetersiz kalmıştır. Ancak bu yetersizlikler sosyolojiden duyulan beklentilerin sona erdiği ya da ereceği anlamı taşımamaktadır. Bununla birlikte Türk toplumunun sahip olduğu sosyal gerçeklikten yola çıkarak Batı sosyolojisi karşısında yerli yaklaşımlar üretilmeye çalışılmıştır. Yerli anlayış(lar)ın geliştirilme çabaları ile birlikte Batı sosyolojisine yüklenen anlam, son bölümde 
değinileceği üzere, Batı merkezli sosyoloji biliminin ne’liği ve kim’liği üzerine günümüz Türk sosyologlarından yola çıkarak yapılacak değerlendirilmelerle ortaya konulacaktır.

\section{Kapitalist Sistemi Meşrulaştıran Batı Merkezli Bir Bilim Olarak Sosyoloji}

Sezgin Kızılçelik'e (2008, s. 9) göre Batı'da sosyolojinin 19. yüzyılda ortaya çıkışı tesadüfi bir durum değildir. Çünkü 19. yüzyılda Batı'nın dünyaya egemen hâle geldiği görülmektedir. Doğu-Batı ilişkilerini istediği şekilde yönetmek isteyen Batı, içeride ve dişarıda bir takım sorunlarla karşılaşmışır. Batı, gerek dünya egemenlik ilişkilerinde dizginleri elinde tutmak ve yayılmacı siyasetini toplumların tamamına yaygınlaştırmak; gerekse sömürüye dayalı kapitalist-emperyalist sisteminin içeride yarattığı buhranları bertaraf etmek, hastalıklı gövdeyi onarmak, ölçüleri bozulmuş bedenleri düzeltmek ve dertlere derman olmak hususunda sosyoloji ilacina büyük bir gereksinim duymuştur. Baykan Sezer'e göre 19. yüzyılda dünya egemenliğini ele geçiren Batı, bu egemenliğin sağladığ1 üstünlükten beklediğinin üzerinde neticeler almaya başlamıştır. Bu durum neticesinde Batı'nın yeryüzündeki gelişmelere istediği yönü verebileceği inancını kazandığını ve bu inancın sonucunda sosyolojinin oluştuğunu belirtmiştir (Kızılçelik, 2009, s. 58-59).

Sosyolojinin ortaya çıkışı ve Batı'da önemsenmesinde Sanayi Devrimi ve Fransız İhtilali'nin önemli yeri bulunmaktadır. Sosyoloji, kendisinin varlık sebebi olan bu süreci kavramaya çalışmış, bir taraftan bu sürecin teorik alt yapısını hazırlamış, diğer taraftan da eleştirel bir tutum takınarak modernitenin ve 18. yüzyll düşüncesinin hem akıl ve birey merkezciliğini hem de sonsuz ilerleme mitini ciddi bir biçimde sorgulamıştır (Ünsaldı \& Geçgin, 2013, s. 29). Böylece kapitalizmin gelişimi noktasında bir zemin oluşturması ve Batı'nın dünya egemenliğini meşrulaştırması adına hizmet eden sosyoloji Batı'da önem kazanmıştır. Baykan Sezer'in (2011, s. 5) de belirttiği üzere 19. yüzyılda bilinen en belirgin özellik, Batı'nın dünya egemenliğini ele geçirmesidir.

Sezgin Kızılçelik'e (2004b, s. 50) göre sosyoloji, söz konusu olan Endüstri Devrimi ve Fransız İhtilali'nin bir sonucudur. Kızılçelik, sosyolojinin bu devrimlerden kaynaklanan hızlı sosyal dönüşümleri araştıran, devlet politikaları için işlevsel olan, yani onları meşrulaştıran bir bilim olduğunu düşünmektedir. Bu bağlamda söz konusu devrimlerin bir ürünü olarak sosyolojinin, kapitalist dünya ekonomisini yönlendiren burjuvazinin sınıfsal çıkarlarına uygun yapıları haklılaştırdığını aktarmaktadır. Böylece sosyolojinin, kapitalist sistemin toplumlar üzerinde büyük bir etki gösterdiği ve Batı'nın dünya egemenliğinde söz sahibi olduğu bir dönemde ortaya çıkmasının tesadüf olmadığı söylenebilir.

Kuşkusuz sosyoloji, modern bir bilimdir (Solmaz, 2013, s. 17). Sosyolojinin 19. yüzyılda Batı'da bilim kimliğine erişmesi, toplumsal ilerleme, değişme, örgütlenme gibi bazı kavramlarla ilişskilendirilmiştir. Sosyoloji, bu yönüyle modern bilim yöntemini ve tarih anlayışını da etkilemiştir. Ertan Eğribel'e (2010, s. 125) göre günümüz tartışmalarının sosyoloji ve modern bilim açısından böyle bir yönü bulunmaktadır.

Batı'da yaşanan devrimler, bir taraftan kapitalist düzenin ve burjuvazinin temellerini sağlamlaştırırken, diğer taraftan da Batı'nın dünya egemenliğini ele geçirmesi hususundaki görüşleri doğrular niteliktedir. Batı'da sosyoloji, böyle bir ortamda ortaya çıkarken, Batı'nın dünya egemenliğine hizmet etmesi kabul edilen bir gerçektir. Bu gerçeği Bat1-diş1 toplumlar perspektifinden yorumlarsak durum bu kadar net görünmemektedir. 19. yüzyılda Batı için sadece olumlu gelişmelerden bahsetmemiz doğru olmayacaktır. Baykan Sezer'in de ifade ettiği üzere 19. yüzyıl, Batı tarihine göre iki açıdan oldukça önemli görülmektedir. Bunlardan ilki, Batı'nın dünya egemenliğini ele geçirmesi ve bunun tarihte eşi görülmemiş boyutlara ulaşmasi; diğeri ise Avrupa'nın batısındaki ülkelerin kendi sorunları ve çekişmeleri dolayısıyla belirli zamanlarda çöküş noktasına yaklaştıklarını düşünmeleridir (Kaçmazoğlu, 2001, s. 11). 
19. yüzyılda Batı, bir taraftan sorunlarla mücadele ederken, diğer taraftan da dünya egemenliğini ele geçirmenin coşkusu içindedir. Burjuvazi, getirdiği düzenin sorunlarını, özellikle Batı'ya özgü toplum içi çekişme ve çatışmaları dünya egemenliği içinde çözme çabasındadır (Sezer vd., 2003, s. 20). Batı'da yaşanan toplumsal sorunlara çözüm aranması, Batı sosyolojisinin ortaya çıkmasında etkili olmuştur. Çünkü aranan çözümlerin sosyolojiden geleceği düşünülmektedir. Sezgin Kızılçelik'e (2004b, s. 59) göre Batı düşüncesinin ürünü olan sosyoloji, Batı'nın kendine has sorunlarıyla belirlenmiş olup, ilgi odağı olarak Batı toplumlarının sorunlarını seçmiştir. Sosyolojinin Batı'nın bilimi olduğunu ve Batı'nın çıkarlarını gözettiğini ifade eden Kızılçelik, Batıdışı mazlum toplumları açıklama kaygısı taşımadığını ileri sürmektedir. O, sosyolojinin Batı'lı ve Batı merkezci olduğunu, Batı-dışı toplumlara karşı önyarg1lı davrandığını düşünmektedir. Ona göre sosyolojinin ortaya çıkışı ve gelişimi, Batı toplumu ve düşünce sistemiyle koşutluk göstermektedir. Batı düşünce sistemi, kapitalist düşünceyi geliştirmek ve bunu tüm dünyaya yaymak amacıyla kendisini geliştirmiştir. Bu zihniyet, burjuvazinin amacina uygun hareket etmek amacıyla pozitivizmi kendisine araç olarak görmüştür. Kızılçelik'in (2004a, s. 94) belirttiği gibi "Batı, özellikle, egemenliği altına almak istediği toplumlar hakkında daha doğru bilgilere gereksinim duyduğu için sosyoloji bilimini çok önemsemiştir. Kısaca, sosyolojinin burjuvazinin çıkarına bir bilim olduğu ve bunu da pozitivizmin sağladığı söylenebilir."

Kapitalist sistemin yaygın hâle geldiği ve Batı'nın dünya egemenliğini ele geçirdiği bir dönemde sosyolojinin ortaya çıkışı tesadüf değildir. Batı toplumunun sosyolojiden beklentileri oldukça fazladır. Sosyoloji, öncelikle toplumların gündelik yaşamlarındaki işleyişin yasalarına ulaşacaktır. Ulaşılan bu yasalara göre, yönetici sınıf, toplumun yönünü kendi menfaatleri (kapitalist sınıfın çıkarları) doğrultusunda şekillendirecektir. Ayrıca yönetici sınıf, sosyoloji aracıllğı ile mevcut toplumsal karmaşayı, "anomi"yi önleyecektir! Bir başka deyişle sosyoloji, maymuncuk gibi her sorunlu kapıyı açacak hale gelecektir. Nerede sorun var ise, sosyoloji oraya koşacak ve sorunu halledecektir (Kaçmazoğlu, 2001, s. 15). Sosyolojinin bilim hüviyetine sahip olması; topluma, bireye, toplum-birey etkileşimine ve dünya gerçekliğine ilişkin fikirler demeti olarak teoriler üretmesiyle ilişkilidir. Sosyolojinin kendisinden söz etmek, sosyolojik teorikleştirme çabalarına gönderme yapmaktan başka bir şey değildir. Sosyolojiden konuşulduğunda "sosyoloji teorileri"nden bahsedilmiş olacaktır. Sosyolojiye dair hasbıhal etmek sosyoloji teorilerini esas almak anlamına gelir. Sosyolojinin ana dayanağı, teoridir. Başka bir deyişle teori, sosyoloji disiplininin omurgasını oluşturur (Kızılçelik, 2015, s. 21).

Batı'nın sosyolojik düşüncesi bir varoluş sorunu olarak başlamıştır. Batı sosyolojisi, ekonomik değişmelerle beliren sosyal krizleri çözüme kavuşturma iddiasında olmuştur (Sağır, 2014, s. 50). Dünya siyasetine yön vermek ve egemenliği ele geçirmek isteyen Bat1, ürettiği teoriler ve geliştirdiği sistematik bir paradigma ekseninde hareket etmiştir. Batı toplumunda görülen sorunların üstesinden gelme yöntemlerini evrenselleştirerek, var olan riskleri azaltmayı başarmışlardır. Böylelikle mücadele ettiği diğer uygarlıkları özellikle batılılaşma anlayışı ekseninde, kendi sınırları çerçevesinde şekillendirme düşüncesinde başarıya ulaşmışlardır. Bu bağlamda Batı, tarihsel olarak krizler ekseninde yenilenmeyi, bir sıçrama varsayımına dayandırmıştır. Nitekim yapısal sorunlarını aşmanın yolunu da dünya egemenliği iddiasında önüne çıan açmazları dönüştürme becerisine bağlamıştır (Öztürk, 2011, s. 9). Ortaya çıkan sonuç, beklenildiğinin aksine, sorunların çözüme kavuştuğu bir dünya düzeni sağlamamıştır. Aksine değerlerin kaybolduğu, tarihin ve toplumun sonuna gelindiği fikrinin baskın hâle geldiği gözlenmiştir. Sezgin Kızılçelik'in (2004c, s. 9) belirttiği gibi "Batı merkezli dünyada insan ve insani olanın kaybolmasıyla yüz yüzeyiz. Bat1, insanı yok eden düzenektir, yani ölülerin ve hortlakların var olduğu mekandan başka bir şey değildir. Batı'nın ördüğü dünya, insanlık dış1 uygulamaların mekanı oldu ve insanlık karşıtı yörüngeye oturdu. Dünya, Batı'yla insanın önemsenmediği bir merkez haline geliverdi." 


\section{Sosyolojinin Ne'liği ve Kim'liği Üzerine Türk Sosyologlarından Değerlendirmeler}

Sosyoloji, Fransız İhtilali'nin ardından Batı'da ortaya çıkan ve gelişen çok boyutlu bir toplumsal gelissmenin ürünüdür (Sezer, 1988, s. 7). Bu gelişmeler, 19. yüzyılda Osmanlı İmparatorluğu'nu tamamen etkisi altına almıştır. Batılı devletler, 19. yüzyılda bir yandan tüm dünyayı sömürgeleştirirken, diğer yandan da tamamen sömürgeleştiremediği Osmanlı ve benzeri ülkeleri çeşitli yollardan ele geçirmeye çalışırlar (Kaçmazoğlu, 2001, s. 13). Sosyolojinin Türkiye'deki serüveninin başlangıcı, Osmanlı'nın son yüzyllına kadar uzanmaktadır. Tanzimat Fermanı ile başlayan Batılılașma sürecinin koșulladığı bu serüvenin öncü adımları 19. yüzyılın sonunda atılır. Bu yüzyıl, büyük kırılmaların, toplumsal ve siyasal dönüşümlerin yaşandığı bir çağı içermektedir. Batı'da kapitalizm olanca hızı ile tüm toplumsal alanlarda belirginleşmeye başlarken Osmanlı İmparatorluğu da bu süreçten farklı boyutlarda etkilenmiştir. Topraklarının emperyalistler tarafindan paylaşılma kavgasının yarattığı dengeden faydalanan Osmanlı idaresi, hem bu sürece direnmenin hem de bozulan nizamı yeniden tahlil etmenin derdine düşer (Ünsaldı \& Geçgin, 2013, s. 215). Türkiye'ye sosyolojinin girişi ve Türkiye'de gelişimi, Batıcılaşma adı altında düzenin yeniden sağlanması adına gerçekleşen girişimlerin vesilesi ile ilk adımlarını atmıstır.

Sosyolojinin evrensel bir bilim hâline gelmesi ve ürettiği teorilerle bütün toplumları açıklayabileceği düşüncesi, kapitalist düşüncenin bir ürünüdür. Kendi sorunlarını çözüme kavuşturmaya çalışan Batı, bir taraftan da Batılı olmayan toplumları açıklama iddiasıyla hareket etmiştir. Sezgin Kızılçelik'in (2005, s. 150) de söylediği gibi "Batı sosyolojisi, Türkiye gibi Batı-dış1 mazlum toplumları açılama iddiasındadır. Batı sosyolojisinin bizim gibi ülkelere önerileri vardır. Batı sosyolojisi, sığındığı evrensellik aldatmacası ve Batı dalkavukları/taparları/işbirlikçileri nedeniyle söz konusu toplumların sosyolojileri üzerinde etkili olmuştur.” Böylece Batı sosyolojisi, kendi çıkarlarını gözeterek kendi dışındaki toplumları izah etmeye çalışmıştır. Öne sürdüğü bir takım teorilerle, Batı-dışı toplumları açıklamak istemiştir. Evrensel bir Batı sosyolojisi anlayışının Batı-dış toplumları tahakküm altına alabilmesi adına küreselleşme adı altında bir çabanın ortaya çıtı̆̆ görülmektedir.

Batı'daki toplumsal, kültürel ve siyasi alanlarda yaşanan gelişmeler, aynı zamanda birtakım sorunları da beraberinde getirmiştir. Korkut Tuna'ya (1991, s. 29) göre sosyoloji, 19. yüzyılda Batı toplumun yaşadığı sorun ve açmazlarına çözüm aramak, büyük sarsıntı ve kriz yaratan olayları yönlendirebilmek amacıyla ortaya çıkmış bir bilimdir. Batı'nın 15-16. yüzyıllardan beri izlenen gelişmesi, toplumlararası ilişkilerde belli bir güce sahip olmasına ve toplumlar arasında gerçekleşen dünya egemenliğini ele geçirmesine yol açmıştır. Sosyolojiye yüklenen görev, sadece Batı'nın dünya egemenliğini meşrulaştırma çabası olmakla kalmayıp aynı zamanda Batı'da yaşanan toplumsal sorunların çözümü noktasında hareket etmesi açısından önem arz etmektedir.

Sosyoloji, burjuva düzenini koruma çerçevesinde, ona tam çeper olma hususunda sosyal tümlügün anlaşılmaması için uzmanlaşma numarası altında başta bilgi dostu felsefe olmak üzere diğer kardeşlerinden (sosyal bilimlerden) düşünsel, teorik ve metodolojik bakımlardan kendisini kopartmıştır. Sosyoloji, burjuva iktidarına siper olmayı, onun ideolojik aygıtı olarak çalışmayı ve muhafizlığını yapmayı devam ettirmektedir. Sosyoloji, burjuvaların yarattığı sosyal çelişkilerin üstüne tül çekmede, burjuva mahallesinden övgüyle söz etmede, onların sıkıntılarını gizlemede ve problematik teşkil eden veçhelerini görmezlikten gelmede oldukça fazla işe yaramıştır. Burjuvazinin kendi imgesinde bir dünya kurma arzusunda onun yanı başında irileşmiş sosyoloji, burjuva değerlerinin dünyaya egemen olmasına koşut olarak yayılmış, kendisine en yakın olanları da Türkiye'den bulmuştur (Kuzılçelik, 2009, s. 9). Böylece Batı sosyolojisi, Batı'da yaşanan toplumsal sorunları açıklayabilmek adına inşa edilirken yaşanan gelişmeler sonucunda Batı düşüncesinin ve burjuvazisinin emrine amade bir bilim dalı hâline gelmiştir. Artık sosyoloji, Batılı 
olmayan toplumları izah etmek gibi yeni bir misyona sahiptir. Batı sosyolojisi, bu yeni misyonu ile Batı'nın sahip olduğu dünya egemenliğinin meşruiyetini kuvvetlendirmek gibi bir amaca hizmet edecektir. Böylelikle sosyolojinin, evrensel bir bilim olması ve bütün toplumları açılayabilir olması yönünde bir anlayışın zihinlere yerleşmesi amaçlanmıştır.

Sosyolojinin değişimi açıklama ve toplumsal sorunlara çözüm getirme işlevlerini yerine getirebilmesi için her şeyden önce Batı'nın ve özellikle Amerika'nın dayatmaya çalıştı̆̆1 küreselleşme sürecinin evrenselleştirici ölçütlerinden ve sanal gerçeklilerinden kurtulması gerekmektedir. Her toplum içinde bulunduğu sosyal realiteye yüzünü çevirmelidir. Bunun için öncelikle yapılması gereken, her toplumun kendi tarihsel gelişimine ve toplumsal koşullarına uygun kavramlar ve teoriler üretmesi ve Batı sosyolojisinin yoğun etkisinden kendisini kurtarmasıdır (Poyraz \& Arıkan, 2003, s. 92). Her toplumsal gerçeklik, birbirlerinden farklılıklar gösterirler. $\mathrm{Bu}$ nedenle sosyologlar da, kendi toplumsal dinamiklerinden hareketle toplumsal tahlillerde bulunur. Zafer Durdu'nun (2014, s. 151-152) ifade ettiği şekliyle "eğer sosyoloji, batılı bir bilim ise ve batının sorunlarını çözmek üzere ortaya çıkmış ise, bu hali ile evrenselleșemez. Evrenselleşememek de, bilim olma iddiasını zedeler. Toplumsal gerçekliği anlamak ve açıklamak isteyen sosyoloji Batı merkezcilikten kurtarılmalı ya da çıkarılmalıdır."

Toplum denen gerçeklik, yere ve zamana göre farkl11ıklar arz etmektedir. Sosyolojinin ilgi odağında yer alan toplum, uygarlıklara göre farklı bir görünüme sahip olmaktadır. Her medeniyetin kendine özgü toplum tasavvuru vardır. Toplum, uygarlıklar itibariyle farklilıklar göstermektedir. $O$ halde tarihsel süreç içinde değişik coğrafyalarda ve kültürlerde ortaya çıkmış "toplum"ları birbirlerinin aynısı ya da muadili olarak değerlendirmek doğru bir yaklaşım değildir. Başka bir deyişle, gerek tarihte gerekse bugün yaşayan toplumlar, birbirlerinin benzeri olarak kabul edilemez. Toplumları aynı kefeye koymak, aynı ölçülerle değerlendirmek, aynı kavram ve kuramlarla açıklamaya kalkışmak, Sezgin Kızılçelik'in (2012, s. 151-152) ifadesi ile "çapsız sosyologların" sıkça yaptıkları bir durumdur. Çünkü her toplum, biriciktir ve kendine has özelliklere sahiptir. Toplumlar, tarihin başlangıcından bu yana birbirlerinden farklılaşmışlar, farklı gelişme çizgileri izlemişlerdir. Bütün bunlara rağmen Kızılçelik'in (2008, s. 119) de belirttiği üzere "Bat1 sosyolojisi, dünyada egemen olan sosyolojidir. Ortaya çıktığı 19. yüzyıldan bu yana başta Türkiye olmak üzere diğer ülkelerin sosyolojilerini tesiri altına almıştır."

18. yüzyılın sonlarından itibaren gerek Osmanlı Devleti'nde gerekse Batı'da ortaya çıkan gelişmeler hem Batılı devletlerin geleceğini, hem de Osmanlı Devleti'nin içinde bulunduğu durumu derinden etkilemiştir. Söz konusu olan durum, etkisini arttırarak 19. yüzyılda da varlık göstermiştir. 19. yüzyllın özellikle ikinci yarısından itibaren Batı, Dünya egemenliğini tartışmasız ele geçirip "vahşi kapitalizm" süreci ile tüm dünya coğrafyasını her şeyi ile sömürge haline getirmiştir (Kaçmazoğlu, 2001, s. 181-182). Böylece Batı, kendi içerisindeki egemenlik mücadelesini genişletmiş ve Batı-dış1 toplumlar üzerinde egemenlik mücadelesini devam ettirmek istemiştir. Yaşanan süreçten nasibini alan ülkelerin başında Osmanlı Devleti gelmektedir. Batı, sahip olduğu kapitalist düzeni devam ettirmek, Bat1-dış1 toplumları da bu düzenin içerisine sokmak istemiştir. Osmanlı Devleti'nde bu durum, Batılılaşma hareketleri çerçevesinde gelişmiştir (Bingöl, 2020, s. 395). Sezgin Kızılçelik'in (2008, s. 143) de söylediği üzere "Batı, kendi sistemini modernleşme ve Batıcılaşma gibi gözde kavramlar yoluyla tüm dünyaya yaymak istemiştir. Bunun için sosyoloji bilimini kullanmıştır. Ona göre, sosyolojinin Türkiye serüveni, bu durumun en belirgin örneklerinden birisini teşkil eder." Çünkü sosyoloji, ortaya çıktığı 19. yüzyıldan bu yana Batı'nın çıarlarını gözeten, Batı'nın dünya egemenliğini meşrulaştıran ve Batı bataklı̆̆ının yayılmasına aracı olan bir bilim olmuştur. Sosyoloji, Osmanlı İmparatorluğu'na da bu bağlamda girmiştir (Kızılçelik, 2008, s. 148).

Günümüzde sosyolojinin 19. yüzyllda Batı'da ortaya çıtktı̆̆ şartlardan daha baş döndürücü çalkantılar, değişmeler, çatışmalar yaşanmaktadır. Bölünme ve çatışmalar daha fazla derinleşerek 
genişlemektedir. Bu durum karşısında, sosyolojiye olan ihtiyacımız daha çok hissedilmektedir. Ancak bu süreçte Batı sosyolojisinin bize yeni bir görüş, yeni bir öneri getirmeyeceği bütün açıklığı ile ortadadır. Batı'nın, Doğu karşısında, imkânı/gücü artmış olmasına karşılık sosyolojinin etkinlik alanı giderek daralmıştır. Batı'nın artık sosyolojiye ihtiyacı bulunmamaktadır (Eğribel, 2010, s. 134). Baykan Sezer'e göre sorunların gerçek açıklamalarının sosyoloji çerçevesi içinde bulunacağ1 kesindir. $\mathrm{O}$, sosyolojide egemen sosyolojinin Batı sosyolojisi olduğunu vurgulamaktadır. Günümüz sosyolojisine genel eğilimlerini, araştırma konularını, kavramlarını ve tartışma alanlarını kazandıran Batı sosyolojisi olmuştur. Bu nedenle bugün sosyolojide genel-geçer sayılan bazı değerlendirme ve kavramların, özellikle kendimizi ve toplumumuzu ilgilendiren konularda temelini bilmek için, Batı sosyolojisinin Doğu toplumları karşısındaki tutumunu bilmek durumundayız. Baykan Sezer'e göre Batı sosyolojisi, Doğu toplumlarını aç1klamakta bazı yetersizlikler, yetersizliklerin ötesinde yanlı bir tutum sergilemektedir. Bat1 sosyolojisinin bu tutumu bilinen bir gerçektir (Sezer, 1991, s. 39). Gerek Batı toplumlarını açıklamada, gerekse bilim hüviyetini kazanmasında Batı sosyolojisinin önemi ve egemenliği yadsınamaz. Fakat günümüz sosyal bilimleri içerisinde Batı sosyolojisinin Batılı olmayan toplumları açıklaması hususundaki yetersizliği de yadsınamayan ayrı bir gerçekliktir. Çünkü dünya toplumlarının ait oldukları uygarlık ve/veya medeniyet, kendi içerisinde bir takım özelliklere sahip olmasından dolayı Doğu ve Batı uygarlı̆̆1 ve/veya medeniyeti şeklinde tanımlanabilir.

Baykan Sezer'e (1993, s. 12) göre ortaya çıkan sosyoloji teorileri içerisinde Türkiye'nin ve Türk toplumunun menfaatleri bakımından olaylara yaklaşabilen, olayları açlklayabilen bir Türk sosyolojisinin kişiliğini elde ettiği zaman ancak biz de bir sosyoloji geleneğimizden söz edebileceğiz. Baykan Sezer (1988, s. 13), Türkiye'de sosyolojinin sorunlarının ortaya konmasında, Türk sosyolojisinin sahip olduğu gelenekleri ve yöntemleri de kurmak zorunda olduğunu öne sürmüştür. Ancak böylelikle Türk sosyolojisinin Türk toplumunun sorunlarına 1şık tutabileceğini düşünmektedir. $\mathrm{Bu}$ yüzden Türk sosyolojisinin yaşanan toplumsal sorunları, bütünlükleri içerisinde değerlendirmek ve böylelikle olayların hakiki anlamlarını gün yüzüne çıkarmakla da yükümlü olduğunu vurgulamaktadır. Günümüzde Türk sosyolojisi kendi çıkarlarını belirlemeye çalısırken dünya sosyolojisi önünde etkili olmaya çalışmaktadır. Batı sosyolojisinin önerilerinin Türk sosyolojisi için geçerli olma zorunluluğu bulunmamaktadır. Bu nedenle Türkiye'de sosyolojinin önü tıkalı değildir ve Batı sosyolojisinin Türkiye'deki şubesi olmakla yetinme lüksümüz de yoktur. Türk sosyolojisinin gelişimi, Batı sosyolojisinden soyutlanamaz fakat Türk sosyolojisi geliştireceği teorilerle (Doğu-Bat1 çatışması teorisi gibi) özgünlüğe erişme yolunda emin adımlarla ilerleyecektir (Sezer vd., 2003, s. 25-26). Böylece Türk toplumunu anlayan ve açıklayan yeni sosyolojik teorilerin inşası için Batı sosyolojisinin ne'liği ve kim’liğinin bilinmesi elzem bir durum haline gelmiştir.

Batı'da sosyoloji, toplumda hüküm süren belirsizlik ortamı içinde ortaya çıan çeşitli düzen veya gelişme/ilerleme arayışlarını temsil ettiği ölçüde başarı, gerçeklik ve uygulama olanağı bulabilmiştir. Ülkemizde ise durum oldukça farklıdır. Osmanlı-Türk aydınının sosyolojiye ilgisi başka nedenlere dayanmaktadır. Siyasal nedenler toplumsal nedenleri öncelemektedir. Başka deyişle sosyoloji ülkemizde, imparatorluğun büyük sorun ve güçlüklerle karşı karşıya geldiği bir dönemde düşünce gündemine gelmiş ve siyasi çözüm arayışlarının bir ifadesi olagelmiştir. Toplum olaylarına ilginin arka planında, kimilerince eleştirel biçimde hep söylenegeldiği gibi "devletin kurtarılması" çabaları yatmaktadır. Batı sosyologlarının çalışmalarına böyle bir kaygının eşlik ettiği söylenemez. "Devlet nasıl kurtarılabilir?" başlıklı bir konu Batılı sosyologların öncelikli bir sorunu olmamıştır. Daha doğrusu böyle bir sorun söz konusu değildir. Sosyoloji, Batı'da daha çok toplum örgütlenmesinin (endüstri toplumunun) yol açtığ1 toplumsal gerilimler ve alacağ1 biçim sorunu üzerinde odaklanmıştır (Özcan, 2010, s. 155). Bu açıdan Türk sosyolojisi, Türk toplum yapısını anlama ve açıklama konusunda teori üretme konusunda Batı sosyolojisini iyi analiz ederek hataya düşmemelidir. 


\section{Sonuç}

Batı merkezli bir anlayışla kapitalist sistemi meşrulaştıran bir anlayışa sahip olan Batı sosyolojisinin Batı-dışı toplumları anlama ve açıklama çabasının/girişiminin beyhude bir çaba/girişim olduğu sonucuna ulaşılmaktadır. Özellikle yerli bir anlayış ortaya koymaya çalışan günümüz Türk sosyologları, bu minvalden hareketle Batı sosyolojisinin ne'liği ve kim'liği üzerine yaptıkları değerlendirmelerle Türk sosyolojisinin kendi teorilerini üreterek Türk toplumunu anlama ve açıklama başarısına ulaşabileceğinin altını çizmektedir. Batı sosyolojisinin ne'liği ve kim’liği üzerine Türk sosyologlarının görüşlerinden yola çıkarak yapılan değerlendirmeler 1şı̆̆ında bir taraftan Türk sosyolojisinin gelişim göstermesi, diğer taraftan da yeni teorilerin üretilmesi sağlanacaktır. Çünkü Türk sosyolojisi, Türk toplumunu anlama ve açıklama noktasında yeni teorilere ihtiyaç duymaktadır.

Doğu toplumlarını açılayabilecek teorilere ihtiyaç elzemdir. Bunun için Batı-dışı toplumları Batı'nın teorilerinden ziyade kendi toplumsal yapılarını açıklayabilecek teorilerin inşa edilmesi gerekmektedir. Türk toplumu gibi Batılı olmayan toplumların izahında gerekli görülen teoriler, bu toplumların medeniyetleri/uygarlıkları nazarında ortaya çıkartılabilir. Bu konuda Sezgin Kızılçelik (2015b, s. 73), Kemal Tahir-Baykan Sezer ikilisinden hareketle, yerli ve millî bir teori olarak Doğu-Batı çatışmasına işaret etmektedir. Kızılçelik, Türk toplumuna Batılı sosyoloji kuramlarının penceresinden bakmaya itiraz etmiștir. Türk toplumunun sorunlarına Doğu-Batı ilişkileri ve çatışması çerçevesinde açıklama getirmiştir. Sadece Türk toplumunu değil, Doğu toplumlarını ve Batı toplumlarını açıklama çabasında olmuştur. Günümüz Türk sosyolojisi içerisinde, Sezgin Kızılçelik dışında H. Bayram Kaçmazoğlu, Ertan Eğribel ve Ufuk Özcan gibi isimlerin de Doğu-Batı çatışması teorisi ile Kemal Tahir-Baykan Sezer ikilisinden hareketle yerli bir anlayıs ortaya koymaya devam etmektedir.

Toplumlar, ait oldukları medeniyet içinde gelişir ve kimlik kazanırlar. Sezgin Kızılçelik'e göre tüm toplumlar, Doğu ve Batı uygarlıklarından birisine mensuptur. Toplumların özellikleri ve sorunları, yer aldığ1 uygarlık göz önünde bulundurularak açıklanabilir. Türk toplumunun ana problemlerinin kaynağı, uygarlık dairesindeki yeriyle doğrudan alakalıdır. Toplumumuzu tanımak, onun özelliklerini ortaya çıkarmak için hangi uygarlığa dahil olduğunu gözler önüne sermek yeterli olacaktır. Sosyologlar, öncelikli olarak yaşadığı topluma onun uygarlık dairesinden bakmakla yükümlüdürler. Kızılçelik'in ifade ettiği şekliyle "bu da ancak yerli sosyologların yapacağı bir iştir. Türk toplumunu ve onun mensubu olduğu uygarlı̆̆ tanımak/bilmek, Batıcı sosyologların değil, yerli sosyologların işidir (2015a, s. 51). Doğu ve Batı toplumları arasındaki farklı özellikler, Kemal Tahir tarafından sıkça vurgulanmıştır. Mülkiyet hakkının, derebeyliğin, asilzadeliğin ve şehir burjuvazisinin Batı'da var olduğunu, buna karşın Anadolu'da olmadığını ileri sürmüştür. Diğer yandan merkezî hükümetin Anadolu'da var olduğunu, Avrupa'da ise bulunmadığını bildirmiştir. Günümüz Doğu toplumlarında, Batı toplumlarında olduğu gibi, ezen ile ezilen arasında büyük çaplı düşmansı ilişkiler mevcut değildir (Kızılçelik, 2012, s. 158-159). Kemal Tahir, Doğu ve Batı toplumları arasındaki farklı özelliklerle ilgili örnekler vermiştir. Bu örneklerden de anlaşılacağı üzere, Doğu ve Batı toplumlarının sahip oldukları toplumsal yapının birbirinden farklilıklar gösterdiği, aynı kavramlar ve teorilerle farklı toplumların birbirini izah edemeyeceği sonucuna ulaşılacaktır. Kızılçelik'in (2015b, s. 25) de ifade ettiği gibi "19. yüzyıldan itibaren Batı sosyolojisinde ortaya çıkan ve günümüze kadar varllğını sürdüren sosyoloji teorilerinin tamamı, Batı toplumlarını açıklamaya dönük teorilerdir. Oysa Türk toplumu, Batılı değil, Doğulu bir toplumdur. Batı toplumlarına dair geliştirilmiş olan söz konusu sosyoloji teorileriyle Doğu uygarlı̆̆ına mensup olan Türk toplumunu aç1klama olanağı bulunmamaktadır."

Gerek Doğu-Batı çatışması teorisi, gerekse Türk toplumunu anlama ve açıklamaya yönelik yeni sosyoloji teorilerinin inşası noktasında Batı sosyolojisinin ne'liği ve kim'liği her yönden iyi bir şekilde tahlil edilmelidir. Bu makale, bu düşünce üzerine kaleme alınmıştır. Batı sosyolojisini yok 
saymak, reddetmek gibi bir amacın/çabanın ötesinde, Türk toplumunu anlamak ve açıklamak noktasında Batı sosyolojisinin yetersiz kalacağı, Batı sosyolojisinin terminolojisi ile Batı-dış1 toplumların objektif şekilde açıklanamayacağı düşüncesi hâsıl olmuştur. Türk toplum yapısının analiz edilebilirliğine imkân tanıyacak yeni sosyolojik teorilerimizin inşası bakımından Batı sosyolojisinin Batı merkezli ve kapitalist sisteme hizmet eden ne'liği ve kim'liğinin idrak edilmesi gerekliliği noktasındaki zaruretin anlaşılabilmesi arzulanmıştır.

\section{Kaynakça}

Bingöl, O. (2020). Tarihi, siyasal ve bilimsel bir tanık olarak sosyoloji: Omanlı imparatorluğu örneği. Journal of Social, Humanities and Administrative Sciences, 6(24), 389-396.

Durdu, Z. (2014). Sosyolojide temel kavramlar ve kurucu fikirler. Detay Yayıncilik.

Eğribel, E. (2010). Toplumsal ilerlemenin ve tarihin sonu: kutsala dönüş. İçinde Ertan Eğribel \& Ufuk Özcan (Eds.). Sosyoloji ynllğ̆z-kitap 20: Türk sosyologlar ve eserleri-1 (125-135). Kitabevi Yayınları.

Kaçmazoğlu, H. B. (2001). Türk sosyoloji taribine giriş-1: ön koşullar. Birey Yayınc1l1k.

Kızılçelik, S. (2004a). Sosyal bilimleri yeniden yapılandırmak. Anı Yayıncılık.

Kızılçelik, S. (2004b). Sefaletin sosyolojisi. Anı Yayıncilık.

Kızılçelik, S. (2004c). Özgünlïğ̈̈n sosyolojisi. Anı Yayınc1l1k.

Kızılçelik, S. (2005). Batı batakliğ. Anı Yayıncılık.

Kızılçelik, S. (2008). Baykan Sez̧er'in sosyoloji anlayısıı. Anı Yayıncılık.

Kızılçelik, S. (2009). Sosyolojinin nelï̆i. Anı Yayıncılık.

Kızılçelik, S. (2012). Özgün ve yetkin bir sosyal teorisyen olarak Kemal Tabir. Anı Yayınc1lık.

Kızılçelik, S. (2015a). Uygarlı, ablak ve eğitim. Anı Yayınc1l1k.

Kızılçelik, S. (2015b). Yerli sosyoloji. Anı Yayıncılık.

Koyuncu, A. A. \& Bozkurt, R. (2019). Yerli sosyolojinin imkanı olarak Baykan Sezer. Anemon Mus Alparslan Üniversitesi Sosyal Bilimler Dergisi, 7(4), 93-100. https://doi.org/10.18506/anemon.543947

Özcan, U. (2010). Türk sosyolojisinin özgünlüğüne dair düşünceler. İçinde Ertan Eğribel \& Ufuk Özcan (Eds.). Sosyoloji yulllŭg-kitap 20: Türk sosyologlar ve eserleri-1 (154-163). Kitabevi Yayınları.

Öztürk, A. (2011). Kriz sosyolojisi: Batı merkezciliğinin yapısal sorunlar ve kriæ. Doğu Kitabevi.

Poyraz, T. \& Arıkan, G. (2003). Geçmişten geleceğe sosyoloji: Bir bilimi yeniden yapılandırma önerisi. İçinde M. Çağatay Özdemir (Ed.). Sorgulanan sosyoloji. (ss. 89-94). Eylül Yayınları.

Sağır, A. (2014). Uygulamal sosyolojik çallşmalar. Siyasal Kitabevi.

Sezer, B. (1988). Türk sosyolojisinin ana sorunlart. Sümer Kitabevi.

Sezer, B. (1991). Batı sosyolojisinin doğu toplumlarına yaklaşımı. İçinde İsmail Coşkun (Ed.). 75. yulında Türkiye'de sosyoloji (ss. 39-47). Bağlam Yayınc1lik.

Sezer, B. (1993). Sosyolojide yöntem tartısmalar. Sümer Kitabevi.

Sezer, B. (2011). Sosyolojinin ana başlkelar. Kitabevi Yayınları.

Sezer, B., Eğribel, E. \& Özcan, U. (2003). Toplum bilimleri ve sosyolojinin sonu görüşleri üzerine. İçinde M. Çağatay Özdemir (Ed.). Sorgulanan sosyoloji (ss. 19-26). Eylül Yayınları.

Solmaz, M. (2013). Etiğin sosyolojik temelleri. Vadi Yayınları. 
Şan, M. K. \& Şenkaloğlu, S. (2019). Batı sosyolojisi karşısında Türkiye'de yerli sosyoloji arayış1. Sosyal ve Kültürel Araștirmalar Dergisi, 5(9), 35-59.

Tuna, K. (1991). Türk sosyolojisinin batı sosyolojisi ile ilişkisi ve sonuçları. İçinde İsmail Coşkun (Ed.). 75. yulinda Türkiye'de sosyoloji (ss. 29-38). Bağlam Yayıncilık.

Ünsaldı, L. ve Geçgin, E. (2013). Dünya'da ve Türkiye'de sosyoloji taribi. Heretik Yayınları.

Zencirkıran, M. (2015). Sosyoloji. Dora Yayınları. 